\title{
Hyperammonemic encephalopathy
}

Time course of MRI diffusion changes

Figure 1 Diffusion-weighted imaging findings

A

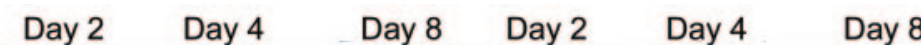

DWI

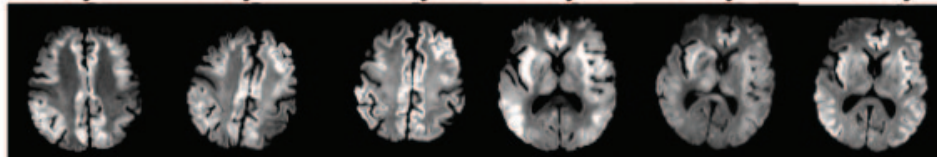

ADC

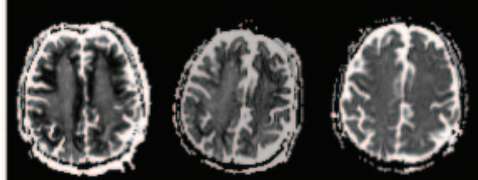

DWI

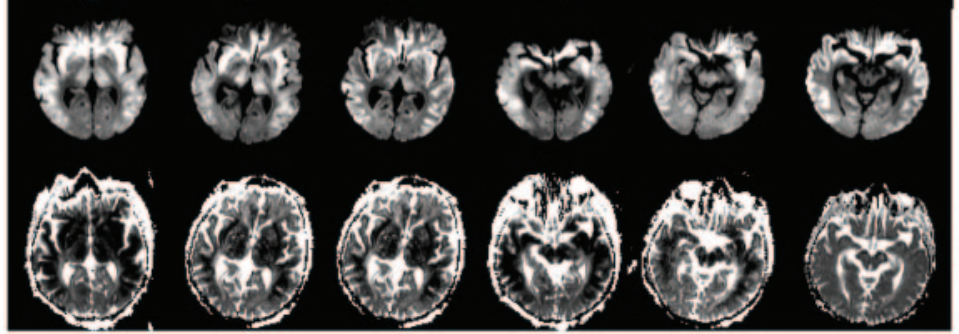

B

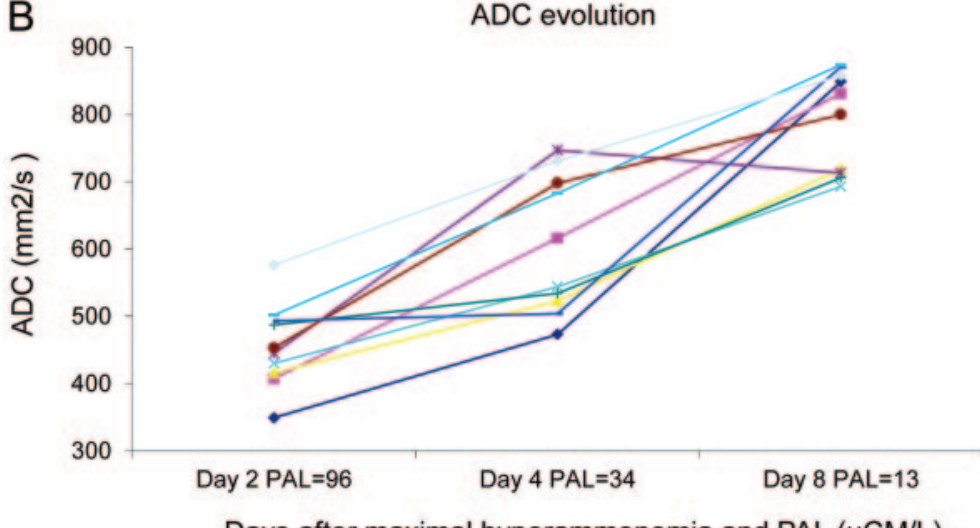

$\rightarrow$ External capsule

- - Internal capsule

- Temporal cortex

$\ldots$ Insula

*-Amygdala

$\rightarrow-$ Frontal cortex

$\longrightarrow$ Midbrain

-Thalamus

Striatum

Parietal cortex

Days after maximal hyperammonemia and PAL $(\mu \mathrm{CM} / \mathrm{L})$

Diffusion-weighted imaging (DWI) signal and apparent diffusion coefficient (ADC) (A) and evolution of $A D C\left(\mathrm{~mm}^{2} / \mathrm{s}\right)$ and plasma ammonia level (PAL) ( $\mu \mathrm{M} / \mathrm{L})(\mathrm{B})$ at 2,4 , and 8 days after maximal hyperammonemia.

A 55-year-old man with cirrhosis presented with hyperammonemic encephalopathy, subsequently fatal (plasma ammonia level $=410 \mu \mathrm{M} / \mathrm{L}$ ). Three-Tesla MRI initially showed restricted diffusion (figure 1A) in the cerebral cortex, suggesting poor prognosis, ${ }^{1}$ thalami, and striatum. Apparent diffusion coefficient pseudonormalized 8 days after admission (figure 1B), comparable to the evolution of hypoxic encephalopathy. ${ }^{2} \mathrm{~T} 2$ hyperintensity of the gray matter progressively increased (figure 2A). High glutamate plus glutamine without lactate was detected on day 2 in the right thalamus, while $N$-acetylaspartate progressively declined (figure 2B). These imaging findings illustrate the time course of hyperammonemic encephalopathy.

A.A. Capizzano, MD, A. Sanchez, MD, T. Moritani, MD, PhD, J. Yager, MS, Iowa City, IA

Author contributions: Dr. Capizzano contributed to the article by overseeing the collection of imaging, MR spectroscopy, and clinical data and writing the original version of the manuscript. Dr. Sanchez contributed to the article by interpreting the clinical data and 
Figure 2 FLAIR and MR spectroscopy findings

A

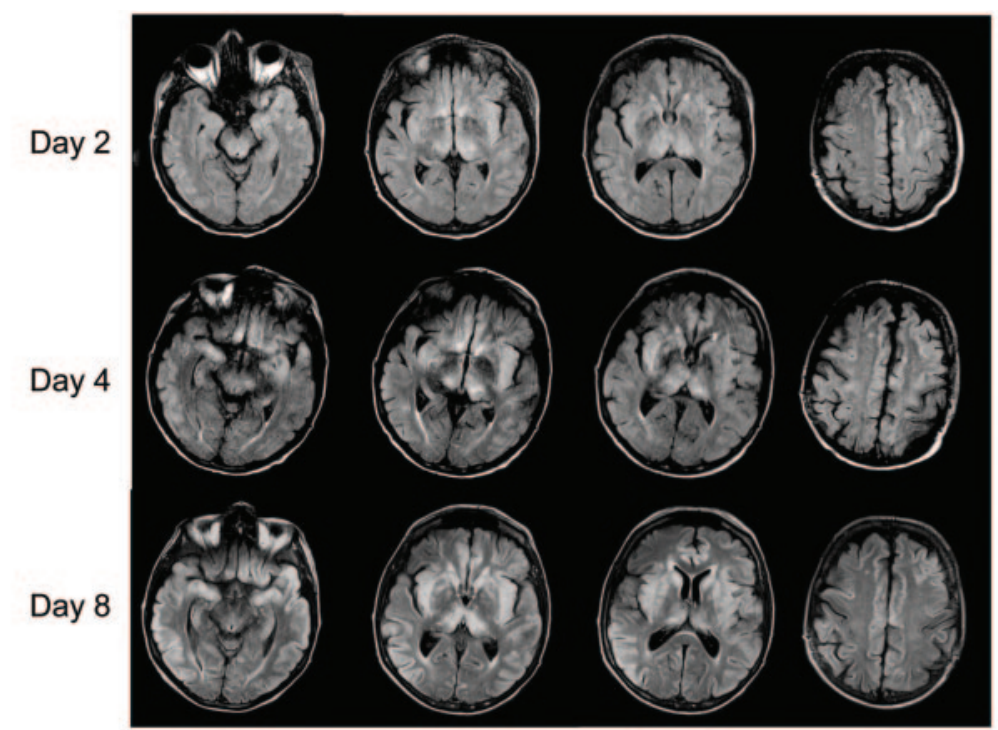

B

Day 2

Day 4

Day 8
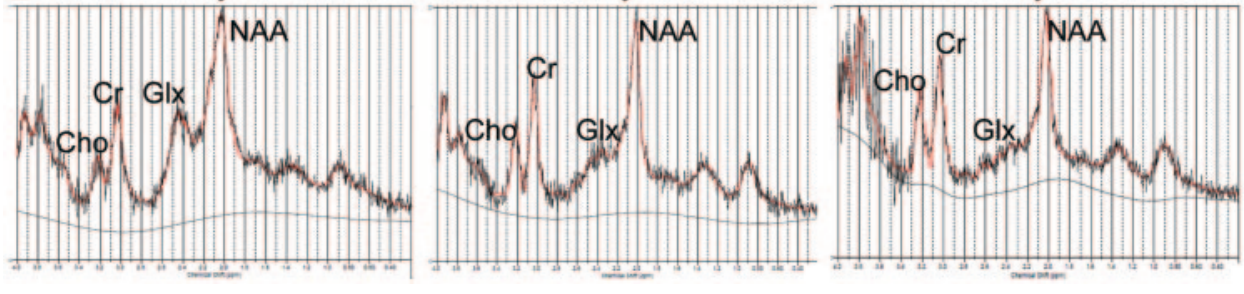

Evolution of fluid-attenuated inversion recovery signal $(\mathrm{A})$ and right thalamic (repetition time/echo time $=1,500 / 30 \mathrm{msec}$ ) metabolites (B) at 2, 4, and 8 days after maximal hyperammonemia.

revising the manuscript. Dr. Moritani contributed to the article by analyzing and interpreting the diffusion-weighted imaging data and revising the manuscript. Dr. Yager contributed to the article by analyzing and interpreting the MR spectroscopy data and revising the manuscript.

Disclosure: Dr. Capizzano reports no disclosures. Dr. Sanchez served on a scientific advisory board for Vertex Pharmaceuticals. Dr. Moritani and Dr. Yager report no disclosures.

Correspondence \& reprint requests to Dr. Capizzano: aristides-capizzano@uiowa.edu

1. McKinney AM, Lohman BD, Sarikaya B, et al. Acute hepatic encephalopathy: diffusion-weighted and fluid-attenuated inversion recovery findings, and correlation with plasma ammonia level and clinical outcome. AJNR Am J Neuroradiol 2010;31: 1471-1479.

2. Huang BY, Castillo M. Hypoxic-ischemic brain injury: Imaging findings from birth to adulthood. Radiographics 2008;28: 417-439. 


\section{Neurology}

\section{Hyperammonemic encephalopathy: Time course of MRI diffusion changes}

A.A. Capizzano, A. Sanchez, T. Moritani, et al.

Neurology 2012;78;600

DOI 10.1212/WNL.0b013e318247ccd1

\section{This information is current as of February 20, 2012}

\section{Updated Information \& Services}

References

Citations

Subspecialty Collections

Permissions \& Licensing

\section{Reprints}

including high resolution figures, can be found at: http://n.neurology.org/content/78/8/600.full

This article cites 2 articles, 1 of which you can access for free at: http://n.neurology.org/content/78/8/600.full\#ref-list-1

This article has been cited by 2 HighWire-hosted articles: http://n.neurology.org/content/78/8/600.full\#\#otherarticles

This article, along with others on similar topics, appears in the following collection(s):

\section{Coma}

http://n.neurology.org/cgi/collection/coma

DWI

http://n.neurology.org/cgi/collection/dwi

Gastrointestinal

http://n.neurology.org/cgi/collection/gastrointestinal

MRI

http://n.neurology.org/cgi/collection/mri

MRS

http://n.neurology.org/cgi/collection/mrs

Information about reproducing this article in parts (figures,tables) or in its entirety can be found online at:

http://www.neurology.org/about/about_the_journal\#permissions

Information about ordering reprints can be found online:

http://n.neurology.org/subscribers/advertise

Neurology ${ }^{\circledR}$ is the official journal of the American Academy of Neurology. Published continuously since 1951, it is now a weekly with 48 issues per year. Copyright Copyright $@ 2012$ by AAN Enterprises, Inc.. All rights reserved. Print ISSN: 0028-3878. Online ISSN: 1526-632X.

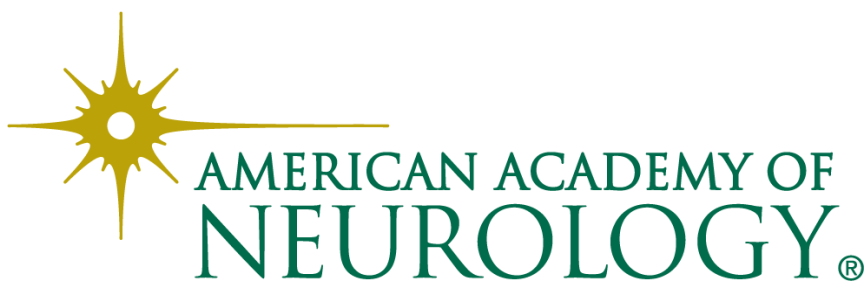

